UNIO - EU Law Journal. Vol. 5, No. 1, January 2019, pp 16-39.

®2019 Centre of Studies in European Union Law

School of Law - University of Minho

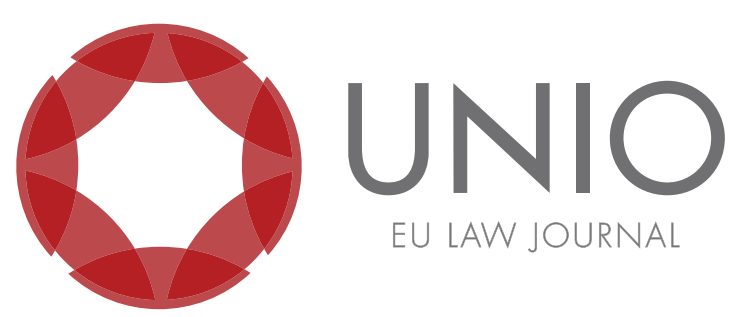

\title{
Digital platforms and European Union law - challenges from a perspective of multilevel constitutionalism
}

\section{Graça Enes*}

ABSTRACT: Present economy and society are under a "digital revolution". Digital platforms connect service and product suppliers to recipients all around the world creating new businesses and changing business models in place. Old-fashioned informal gig-economy and sharing practices by using the new technology seem to change consumption and production patterns to more efficient and sustainable ones... or maybe not. This "new economy" also poses several challenges to law questioning the adequacy of concepts and regulations in force. Disputes with authorities and incumbent industries end up in violence or in courts, including the European Court of Justice. We intend to give an overview of those challenges, especially in light of European Union law and following a multilevel constitutionalist approach, which we believe is best suited to respond to the regulatory challenges of this "new economy".

KEYWORDS: digital platforms - sharing economy - European Union law - competences multilevel constitutionalism.

\footnotetext{
${ }^{*}$ Professor at the Faculty of Law of the University of Porto.
} 


\section{Introduction}

The revolutionary significance of digital platforms to the economy and business was proclaimed ${ }^{1}$. Digital platforms are considered as the engine of a "new economy" and the core of all new business models not for the future, but right now. ${ }^{2}$ In fact, we are witnessing a societal revolution that brings us closer to McLuhan's "global

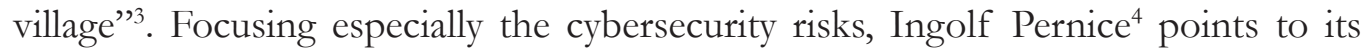
constitutional relevance, and speaks of a "digital society" as a "digital constellation" with new opportunities and risks for Law, Governance and Democracy and proposes a multilevel constitutionalist approach. In our view, the regulatory challenges posed by digital platforms on the so-called "sharing/collaborative economy" have a constitutional relevance and should be approached from a multilevel constitutionalist perspective as well.

Besides transformations in long existing industries, like automobile, health, financing, and education, digital platforms brought the emergence of the "sharing/ collaborative economy", disrupting tourism or urban mobility. Brian Walsh labelled the "sharing economy" as "one of the 10 ideas that will change the world." 5 They induced major social changes, namely allowing many people with middle income to travel and others to work escaping unemployment or getting an extra-income.

What is the significance of this revolution? The views differ. ${ }^{6}$ The data on the under-utilization of cars in some EU Member States predict the efficiency and sustainability potential of the sharing economy. ${ }^{7}$ Some authors are more sceptical

\footnotetext{
${ }^{1}$ Geoffrey Parker, Marshall W. Van Alstyne and Sangeet Paul Choudary, Platform Revolution. How networked markets are transforming the economy and how to make them work for you (NY/London: W. W. Norton \& Company Ltd, 2016).

2 According to Accenture, digital economy accounted for $22 \%$ of global GDP in 2015. A poll in the US showed that in January $201642 \%$ of Americans have already used a sharing economy service and 22\% provided one. Accenture Technology Vision 2016 People First: The Primacy of People in a Digital Age, 2016, p. 6, accessed November, 10, 2018, https://www.accenture.com/t20170227T030304Z__w_/us-en/_ acnmedia/PDF-20/Accenture-Technology-Trends-Technology-Vision-updated.pdf. The figures in Japan are very different with no more of $1 \%$ using such a service. See Michael A. Cusumano, "The Sharing Economy Meets Reality," Communications of the ACM, vol. 61, No. 1 (January 2018): 26-28, http://www. teic.tus.ac.jp/wp-content/uploads/2016/11/Puzzle_of_Japanese_Innovation_and_Entrepreneurship. pdf. In the European Union the percentage of users in April 2018 was 23\% (in 2016 the proportion was 17\%). European Union, “The Use of Collaborative Platforms", Flash Eurobarometer 438, March 2016, p. 4, http://ec.europa.eu/COMMFrontOffice/publicopinion/index.cfm/Survey/getSurveyDetail/ instruments/FLASH/surveyKy/2112; European Union, "The Use of the Collaborative Economy”, Flash Eurobarometer Report 467, 2018, p. 4, http:// ec.europa.eu/commfrontoffice/publicopinion/index.cfm/ survey/getsurveydetail/instruments/flash/surveyky/2184. On the other hand, this last survey reveals that only $6 \%$ of Europeans offer services via collaborative platforms, and only $1 \%$ on a regular basis. (p. 6). Accommodation (57\%) and transport (51\%) are the main services provided via platforms (p. 4).

3 This expression was part of the speech "The medium is the message" made in 1967 at the National Broadcasting Corporation, accessed December 28, 2018, http:/ /www.marshallmcluhanspeaks.com/. 4 "Risk management in the digital constellation - a constitutional perspective", Part I and Part II, IDP - Revista de Internet, Derecho y Politica, n. 26 , (February 2018): 83-94 and No. 27 (September 2018): 79 95, http://dx.doi.org/10.7238/idp.v0i26.3124 and http://doi.org/10.7238/idp.v0i27.3125.

5 “Today's smart choice: Don't own. Share”, Time, March 17, 2011, http:/ / content.time.com/time/ specials/packages/article/0,28804,2059521_2059717,00.html.

${ }^{6}$ For an overview of different approaches, Will Sutherland and Mohammed Hossein Jarrahi, "The Sharing Economy and Digital Platforms: A Review and Research Agenda," International Journal of Information Management Volume 43 (December 2018): 328-341, https://doi.org/10.1016/j.ijinfomgt.2018.07.004.

${ }^{7}$ European Parliament, The Cost of Non-Europe in the Sharing Economy. Economic, Social and Legal Challenges and Opportunities, January 2016, p. 82-84, http://www.europarl.europa.eu/thinktank/en/search.
} 
and highlight the negative consequences on workers' rights and conditions, ${ }^{8}$ risks for consumers' protection, ${ }^{9}$ liability issues ${ }^{10}$ and disruption of fair competition and of public policy requirements, ${ }^{11}$ gentrification of cities and rise of house rentals. ${ }^{12}$ This economic sector is very diverse, ranging from global "unicorns", with market capitalization of billions of dollars, even if some have no profits yet, ${ }^{13}$ to micro companies struggling to survive.

Enthusiasm about "sharing/collaborative economy" has cooled. If the news on death of a truly "sharing economy" are surely exaggerated, it is worth noting that people's interest is bigger in Latin America and Asia-Pacific than in Europe or North America. ${ }^{14}$ Explanations may be the absence of regulated trustworthy services, the importance of informal economy and the appealing drive of modern, easily accessible and less costly services ${ }^{15}$ China, in turn, has been revealed to be a difficult market for western platforms like Uber that, after heavy losses, finally gave up. ${ }^{16}$ In Europe and North America, the digital platform ecosystem is dominated

html?word=sharing+economy; Rachel Botsman and Roo Rogers, What's Mine Is Yours (New York: Collins, 2010); Boyd Cohen and Jan Kietzmann, "Ride On! Mobility Business Models for the Sharing Economy," Organization \& Environment 27 (2014): 279-96, https://papers.ssrn.com/sol3/papers. cfm?abstract_id=2519349.

${ }^{8}$ Robert Reich, "Why the Sharing Economy is Hurting Workers-and what must be done," 27 November 27, 2015, http://robertreich.org/post/134080559175; Carles Muntaner, "Digital Platforms, Gig Economy, Precarious Employment, and the Invisible Hand of Social Class," International Journey of Health Sciences (September 2018): 597-600, https:/ / doi.org/10.1177/0020731418801413.

${ }^{9}$ Christopher Koopman, Mathew Mitchell and Adam Thierer, “The Sharing Economy and Consumer Protection Regulation: The case for Policy Change," The Journal of Business, Entrepreneurship \& the Law Volume 8, Issue 2 (2015): 529-545, https:/ / digitalcommons.pepperdine.edu/cgi/viewcontent.cgi? ref erer $=\&$ httpsredir $=1 \&$ article $=1130 \&$ context $=$ jbel.

${ }^{10}$ Albert Ruda Gonzalez, "Responsabilidad por hechos ajenos en la economia colaborativa. El caso de Uber", Collaborative Economy: Challenges and Oportunities. Proceedings of the $14^{\text {th }}$ Conference on Internet, Law \& Politics, Universitat Oberta de Catalunya, Barcelona, 21-22 June, 2018, (Barcelona: Huygens Editorial, 2018), 424-440, http://symposium.uoc.edu/_files/_event/_12116/_editorFiles/file/ IDP_2018_oct18\%20(1).pdf. The main disadvantage users pointed to the collaborative platforms was "not knowing who is responsible in the event of a problem with the service provided through the platform." European Union, “The Use of Collaborative Platforms," Flash Eurobarometer 438, March 2016, p. 4; in a more recent survey done in April 2018 and published in October 2018 liability continued to be the major concern. European Union, "The Use of the Collaborative Economy," Flash Eurobarometer Report 467, 2018, p. 4, http:// ec.europa.eu/commfrontoffice/publicopinion/ index.cfm/survey/getsurveydetail/instruments/flash/surveyky/2184.

${ }^{11}$ In addition, the environmental and social benefits are yet to prove. Koen Franken and Juliet Shor, "Putting the Sharing Economy into Perspective," Environmental Innovation and Societal Transitions 23 (2017), 3-10, http://dx.doi.org/10.1016/j.eist.2017.01.003.

${ }^{12}$ Paula Imperatore, "Airbnb and the City: one conflict, two ideas of city. The case of Barcelona", Collaborative Economy: Challenges and Oportunities. Proceedings of the $14^{\text {th }}$ Conference on Internet, Law \& Politics. Universitat Oberta de Catalunya, Barcelona, 21-22 June, 2018 (Barcelona, Huygens Editorial, 2018), 308-325, http://symposium.uoc.edu/_files/_event/_12116/_editorFiles/file/IDP_2018_oct18\%20 (1).pdf.

${ }^{13}$ Uber is to be valued at $\$ 120$ billion. Trefis Team, "How Uber could Justify a $\$ 120$ billion valuation", Forbes.com, December 3, 2018, https://www.forbes.com/sites/greatspeculations/2018/12/03/howuber-could-justify-a-120-billion-valuation/\#5b3d2cea7f9b.

${ }^{14}$ Nielsen, "Global Consumers embrace the Share Economy", May 28, 2014, https://www.nielsen. com/lb/en/press-room/2014/global-consumers-embrace-the-share-economy.html.

15 Adam Ozimek and Modeled Behaviour, "The Sharing Economy And Developing Countries," Forbes, August 4, 2014, https://www.forbes.com/sites/modeledbehavior/2014/08/04/the-sharingeconomy-and-developing-countries/\#7f6081b27e0b.

${ }^{16}$ Ronaldo C. Parente, José-Maurício G. Geleilate, and Ke Rong, “The Sharing Economy Globalization 
more and more by companies, and the regulatory constraints imposed may help to explain that. ${ }^{17}$ Scandals surrounding the most prominent platforms revealed a dark "face" of the "sharing/collaborative economy". The days of innocence are over. Law, at the various levels, European, national, and local, must be aware of the diverse effects, risks, different regulatory demands, and of the potential benefits for the economy and society.

There is a consensus that digital platforms pose major challenges to business but also to law, questioning long accepted frameworks, principles and concepts. In fact, there is no legal certainty. Are they out of the scope of existing regulations or does the fragmented regulation in force across sectors and nations, regions and cities, apply to them? Are old concepts and rules still fit or does this new business model demand new regulations? Should the EU enact new rules? One thing is undeniable, recent as it is, the platform business has proved to be a very litigious economic sector all around the world, particularly involving ride services company Uber. ${ }^{18}$ Only within the European Union judicial system since 2015, there were four cases relating to Uber. ${ }^{19}$

Our purpose is to discuss some of the legal challenges, identified especially in regard to transport platforms. We believe that the answer to these challenges is the theoretical framework of multilevel constitutionalism and taking into account some of its fundamental and operating principles, in particular, subsidiarity.

\section{Digital platforms and "sharing economy". Understanding a new business model}

\section{What are we talking about when we talk about "Sharing Economy?"}

There is no consensus surrounding this new economic reality, ${ }^{20}$ beginning with the name itself. ${ }^{21}$ Starting with the European Institutions, the European Parliament speaks of "sharing economy" whereas the European Commission speaks of

Phenomenon: A Research Agenda," Journal of International Management, vol. 24, Issue 1, (March 2018): 52-64, 56-57, https://ac.els-cdn.com/S107542531730162X/1-s2.0-S107542531730162X-main.pdf?_ tid=739dbe4a-650a-413b-9e24-dd5895c3f306\&acdnat=1547942071_11b6bf80378c3652f68eee72bf88 29ed.

${ }^{17}$ The conditions imposed by rules in Portugal to urban mobility platforms or hosting are very hard to meet by non-professional providers. Like happened in other cities, in Lisbon and Oporto the hosting business ("alojamento local") is more and more concentrated and run professionally including hotel conglomerates. Ride hailing is dominated more and more by rental companies that counterpart with Uber and hire the drivers. The new Portuguese law will favour that trend. On the uneven distribution of economic benefits see Franken and Shor, "Putting the Sharing Economy into Perspective...", 7.

${ }^{18}$ In the US, between 2012 and 2015 Uber was involved in 173 lawsuits. Leila Abboud and Jeremy Wagstaff, "INSIGHT-Legal troubles, market realities threaten Uber's global push," Reuters, October 5, 2015, https:/ /www.reuters.com/article/uber-global-idUSL1N1203IE20151005.

${ }^{19}$ A recent reference from the "Juge d'instruction du Tribunal de Grande Instance de Paris" (Case C-390/18) concerns Airbnb services questions the possible conflict between its services and rules relating to the exercise of the profession of real estate agent in France, laid down by Law No. 70-9 of 2 January 1970 on intermediaries in real-estate transactions ('the Hoguet Law').

${ }^{20}$ Rachel Botsman, "The Sharing Economy Lacks a Shared Definition," FastCompany, November 21, 2013, https://www.fastcompany.com/3022028/the-sharing-economy-lacks-a-shared-definition\#10.

${ }^{21}$ On the multiple terms and concepts find in literature, see Georgina Görög, "The Definitions of Sharing Economy: A Systematic Literature Review," Management 13, n. 2 (Summer, 2018): 175-189, https://doi.org/10.26493/1854-4231.13.175-189. 
"collaborative economy". Georgina Görög ${ }^{22}$ found 26 terms associated with digital platform business models. We face "floating signifiers" 23 and semantic disputes ${ }^{24}$ but also epistemic controversies with important implications. This sector has a very diverse scope and labels and definitions may validly vary depending on the focus of the analysis.

The European Parliament ${ }^{25}$ highlights the efficiency promoted by digital platforms by improving the hiring ("sharing") of assets, reducing their underutilisation. After the monetizing evolution and professionalization, "sharing" is not the right term and "access economy" should be preferred. "Sharing," points to optimize the use of underutilized assets and most of services provided through digital platforms now do not meet that requirement. In an "access economy", the purpose is not to own but to use assets, changing the pattern of economic activity and overcoming the traditional selling/buying one. In this economic and social model, value does not rest in ownership but in access to use. ${ }^{26}$ That is a new paradigm for "liberal" XIX century law after the first challenge posed by intangible assets of the global finance economy.

"On-demand economy" is another proposal. "sharing" would restrict interactions to the consumer-to-consumer interaction for temporary access of physical goods. This is too narrow, because there is no reason not to include the provisions of services in a non-professional way. The issue is that most of the times, services provided in platforms, even if they are not professional (they are performed on spare time and provided on a task basis), they represent the old informal "gig economy" now using cutting-edge technologies reaching worldwide. ${ }^{27}$

Another definition is "crowd economy" 28 and this may be a two-sided form of popular capitalism. Platforms connect a global crowd of insulated service providers to a global crowd of consumers, and they all contribute to the platform ecosystem feeding the "network effects" essential in this business model.

A very strict semantic approach could have very little economic significance. ${ }^{29}$

\footnotetext{
${ }^{22}$ The Author presents definitions of the most prominent 15 popping in google search results. After "digital economy", a general expression for any economic activity enhanced through digital technology, "sharing economy" is the most popular one. Georgina Görög, "The Definitions of Sharing Economy”, 180-181.

${ }^{23}$ Cristiano Codagnone, Federico Biagi and Fabienne Abadie, The Passions and the Interests: Unpacking the Sharing Economy, Institute for Prospective Technological Studies. JRC Science and Policy Report EUR 27941 EN, 2016, doi:10.2791/474555. http://publications.jrc.ec.europa.eu/repository/bitstream/ JRC101279/jrc101279.pdf.

${ }^{24}$ Russull Belk, "Sharing v. pseudo-sharing in web 2.0," Anthropologist, vol. 18, issue 1 (2014): 7-23, http:// www.krepublishers.com/02-Journals/T-Anth/Anth-18-0-000-14-Web/Anth-18-1-000-14-Abst-PDF/ T-ANTH-18-1-007-14-1106-Belk-Russ/T-ANTH-18-1-007-14-1106-Belk-Russ-Tx\%5b2\%5d.pdf.

${ }^{25}$ European Parliament, The Cost of Non-Europe..., I-43.

${ }^{26}$ Asta Daunoriené, Aura Drakšaité, Vytautas Snieška, and Gitana Valodkiené, "Evaluating Sustainability of Sharing Economy Business Models," Procedia: Social and Behavioural Sciences 213 (2015): 836-841, https://ac.els-cdn.com/S1877042815058413/1-s2.0-S1877042815058413-main.pdf?_tid=eb6ffcda8b07-487b-8e33-189477432d8a\&acdnat=1547944105_d467a7aba5867d84855ddabb9d8f9451.

${ }^{27}$ The crudest example is the platform "Mechanical Turk". It can be viewed as a rebirth of the preindustrial economy of homemade task work now performed by a multinational multitude of isolated workers incapable of organizing and defending their interests in face of anonymous global counterparts. For Robert Reich it risks being a regression. Robert Reich, "Why the Sharing Economy is Hurting Workers...". ${ }^{28}$ Arun Sundararajan, The Sharing Economy, The End of Employment and the Rise of Crowd Based Capitalism (Cambridge, MA: The MIT Press, 2016).

${ }^{29}$ European Parliament, The Cost of Non-Europe..., I-43.
} 
Definitions too broad or too narrow may not be useful ${ }^{30}$ but also, the absence of a definition about the concept and its scope makes it more difficult to have a common approach at the European level. ${ }^{31}$ For that reason, the European Institutions present broad concepts and admit that the regulatory approach must be cautious, diverse-aware and on a case-by-case basis. This is most important as this is not a mature field and innovation is paramount.

Aware of all that, a pragmatic view focused on the potential benefits and on risks is wise. In 2015, the European Commission ${ }^{32}$ presented the following definition of "collaborative economy": "a complex ecosystem of on-demand services and temporary use of assets based on exchanges via online platforms".

Many of the services that provided B2C ("business to consumer") are new means of rental. Sharing assets like households or cars, or commodities like tools is not a new phenomenon but its reach was limited to friends and neighbours (at the most, real estate brokers established locally mediated it). P2P ("peer to peer") C2C ("consumer to consumer") are as old as human relations and the twist given by digital platforms, besides a modern and trendy patine, is that a service with only local/regional or at the most, national reach now reaches globally ${ }^{33}$ and allows for increased efficiency and new earnings. Digital platforms improved information about assets, counterparts and improved the security of contracts and payments, reducing the transaction costs.

Digital platforms may be a new business or not. They may be a very efficient instrument of an intermediation service (in itself an old business), connecting service providers to potential clients. It may be a new tool in long established industries like automobile or health changing their business models. ${ }^{34}$ Under the designation of "sharing/collaborative economy", we find very different realities, profit and nonprofit, local and global, specialised and non-specialised. ${ }^{35}$ Maybe a more careful look is in order to find out very different business surrounding platforms. Focusing on mobility only, there are platforms that simply provide an intermediary service without any control over the transport between professional drivers and customers (My'Taxi), others that connect a driver willing to share a journey with someone to split the costs (Blablacar), and others that organise a transport service on-demand for a passenger for a journey that otherwise would not take place (Uber). ${ }^{36}$

In common, there is the use of a digital platform to develop production or consumption relations.

\footnotetext{
${ }^{30}$ Advocate-General Macjel Szupnar considers that a broad definition such as the Commission one is useless for drawing any legal framework (Opinion, case C-434/15, "Elite Taxi”, footnote 13).

${ }^{31}$ Vassilis Hatzopoulos and Sofia Roma, "Caring for Sharing? The Collaborative Economy under EU law,” Common Market Law Review 54, Issue 1 (2017): 81-128, 84.

${ }^{32}$ European Commission, Public Consultation on the regulatory environment for platforms, online intermediaries, data and cloud computing and the collaborative economy, 2015, p. 3, https://ec.europa.eu/digital-singlemarket/en/news/public-consultation-regulatory-environment-platformsonline-intermediaries-dataand-cloud.

33 Graça Enes, "The collaborative economy as a matter of competences between the EU and Member States. The case(s) of Uber," Collaborative Economy: Challenges and Oportunities. Proceedings of the $14^{\text {th }}$ Conference on Internet, Law \& Politics. Universitat Oberta de Catalunya, Barcelona, 21-22 June, 2018 (Barcelona, Huygens Editorial, 2018), 381-395, 382, http://symposium.uoc.edu/_files/_ event/_12116/_editorFiles/file/IDP_2018_oct18\%20(1).pdf

${ }^{34}$ What was certainly new were the digital technologies that allowed the creation of digital platforms but this is not our subject.

${ }^{35} \mathrm{~B} 2 \mathrm{~B}$ platforms get less attention.

${ }^{36}$ Franken and Shor, "Putting the Sharing Economy into Perspective...", 5, ftn. 1.
} 


\section{Digital platforms, the core of a new business model. The case of transport and accommodation platforms}

\subsection{Digital platforms - a new business model}

Do digital platforms change the nature of the economy and society or, at the least, of business? ? $^{37}$ Platforms were identified as "the most profound disruptive change in the global macroeconomic environment since the Industrial Revolution." 38 May digital platforms be compared to the steam machine or the internal combustion engine? In fact, even if the business is not new, the business model seems to be new and revolutionary in economy and society. We will restrict our analysis to business and especially to mobility platforms, but the same evolution is seen in societal values and vindications. ${ }^{39}$

Let us start with the puzzling words of Tom Goodwin, Sr. VP of "Strategy Havas Media": "In 2015, Uber the world's largest taxi company owns no vehicles, Facebook the world's most popular media owner creates no content, Alibaba the most valuable retailer has no inventory, and Airbnb the world's largest hotelier owns no real estate". 40

Reliance on external suppliers and the absence of ownership of the physical assets used in the services provided is the common DNA to the most prominent digital platforms. ${ }^{41}$ This feature is not negative and makes it possible to grow worldwide much easier because they do not have the huge costs implied by owning local assets and risk is shifted to micro-entrepreneurs. The major 15 'platform' companies represent $\$ 2.6$ trillion in market capitalization and are stars of capital investment "angels" 42 that made them "unicorns". Their almost unique asset is the virtual platform and their investment focus on technology development, intermediation, market strategies, and customer service, allows them to be simple and agile organisations. A good example is Uber: it operates in more than 60 countries and had total revenues of more than $\$ 1.5$ billion in 2015 , and still "coordinates all operations such as software development, marketing, and legal issues from its San Francisco headquarters." ${ }^{33}$

This digital platform business is an extremely dynamic and innovative business, though the most important innovations are not products or services but the change platforms induce in business models. ${ }^{44}$ That is why also incumbent industries under the competitive challenge from those platform industries and every other business, from major global corporations to local service providers or start-ups, are rapidly following the move to digital platforms and are deeply changing their competitive strategy

\footnotetext{
${ }^{37}$ A systematic review of literature on platforms can be found in Llewellyn D. W. Thomas, Erkko Autio and David M. Gann, "Architectural Leverage: Putting Platforms in Context," Academy of Perspectives, vol. 28, No. 2, 2014, https://doi.org/10.5465/amp.2011.0105.

${ }^{38}$ Accenture, Accenture Technology Vision 2016..., 45.

39 The "punchline" "if it's not on the internet it doesn't exist" represents well this new societal trend. A new digital society inherently global is being built and "[it] reflects a level of social and communicative relations among people that is comparable to those at the local, regional, national and supranational levels of society, though still more informal and with less attachment." Ingolf Pernice, "Risk management in the digital constellation ... (part I)", 90.

${ }^{40}$ Apud Hamish McRae, "Facebook, Airbnb, Uber, and the unstoppable rise of the contentnon-generators," Independent, 5 May 5, 2015, https://www.independent.co.uk/news/business/comment/hamish-mcrae/ facebook-airbnb-uber-and-the-unstoppable-rise-of-the-content-non-generators-10227207.html

${ }^{41}$ Parker et al., "Platform Revolution...", 2.

${ }^{42}$ Accenture, Accenture Technology Vision 2016..., 38.

${ }^{43}$ Parente et al., "The Sharing Economy Globalization Phenomenon...", 54.

${ }^{44}$ Accenture, Accenture Technology Vision 2016..., 37.
} 
and business model. ${ }^{45}$ Digital platforms integrate with dominant corporations and these become platform based. ${ }^{46}$ Moreover, disruption goes on with spill-over across sectors. An illustrative example is Uber: after disrupting the taxi industry, it organised UberEats, and recently went into health industry with UberHealth. ${ }^{47}$ In addition, Airbnb expanded its services from accommodation to "touristic experiences" with local providers.

This new business model works as a complex "ecosystem" and its operative core is the digital platform around which products and services are designed and organised, all stakeholders and customers, and even public authorities interact and evolve, in sum all value is created.$^{48}$ In "ecosystems" all participants provide services to the "community" and are mutually dependent, be it the connection, the ride, the organising of all interactions, and even the comments posted that feed the reputational system of quality control. The respective role may be complementary and even blurred (a 'producer' is also a 'consumer' becoming a 'prosumer').

In this sense, digital economy is inherently a "collaborative economy". Contrary to traditional product business models that are linear, this new model is driven by "demand economies of scale", the so called "internet effects", connecting and mutually benefiting producers, consumers, developers and other stakeholders and it works by multiple inputs and feedback. Finally, these new "ecosystems" are open marketplaces that range across the globe, ${ }^{49}$ overstepping borders, turning local business global, and making global business locally relevant because of the disruptive effects they have on that level. It is precisely this global reach of "internet effects" that allow the continuing expansion of providers and clients that promote the exponential growth of the most successful platforms. ${ }^{50}$

In 2016, the European Commission explains further this "complex ecosystem": "[it] refers to business models where activities are facilitated by collaborative platforms that create an open marketplace for the temporary usage of goods or services often provided by private individuals. (...) involves three categories of actors: (i) service providers who share assets, resources, time and/or skills - these can be private individuals offering services on an occasional basis ('peers') or service providers acting in their professional capacity ('professional services providers'); (ii) users of these; and (iii) intermediaries that connect - via online platform - providers with users and that facilitate transactions between them ('collaborative platforms')."

\footnotetext{
${ }^{45}$ Parente et al., "The Sharing Economy Globalization Phenomenon...", 56.

${ }^{46}$ Uber ensured an association with complementary industries like Hertz, Toyota (this corporation has recently invested $\$ 500$ million in Uber) or Volvo to facilitate drivers' access to rental or lease services. Lyft associated with General Motors. MyTaxi is part of the Daimler group. BMW has its own transport ride platform - Car2go. Parente et al., "The Sharing Economy Globalization Phenomenon...", 55-56. The other side of the coin is the risk of monopoly and fewer benefits spread to developers or consumers.

${ }^{47}$ Accenture, Accenture Technology Vision 2016..., 51.

${ }^{48}$ Accenture, Accenture Technology Vision 2016..., 37.

${ }^{49}$ Parente et al., "The Sharing Economy Globalization Phenomenon...", 52-64.

${ }^{50}$ Recent studies, nevertheless, identify limits to growth in mobility platforms resulting from the fragmented and local nature of the transport service provided that limit the demand. The same holds for temporary accommodation. Tourism may be an important contribution to overcome this fragmentation but that too is subject to economic floating. Regulations may also impose limits and increase costs, as became evident in numerous cities around the world. Michael A. Cusumano speaks of "facing the reality", "The Sharing Economy faces Reality", 27. The Author foresees a shadow future for Uber. For a very positive view, Trefis Team, "How Uber could Justifie...". Solicitar a autora que verifique a referência em destaque, pois o título previamente citado deste autor é "The Sharing Economy Meets Reality" (nota n. 2)
} 
Collaborative economy transactions generally do not involve a change of ownership and are carried out for profit or not-for-profit. ${ }^{51}$

In this new collaborative business model, value is created from developers and even consumers outside the core company/platform. This may well be a positive means of creating new significant communities across the world but there are risks that may demand regulatory control, for instance, the risk of predatory behaviour of giant platforms exploring local providers such as drivers. Also, negative externalities, especially at local level, be they on incumbent industries or related to public policy requirements deserve attention from regulatory authorities.

Because of the diversity of this sector, regulatory demands are not uniform, and any regulatory intervention must be diversity aware and must understand the business under scrutiny and its economic and societal impact very well.

\subsection{The "business" of transport and accommodation platforms}

We are certainly before a new business model but that does not mean necessarily that the business itself is new. What is the nature of mobility platforms business? This too is relevant to approach the regulatory issues at stake. The cases involving Uber in the CJEU had these questions at heart. Uber claimed to be an information society service provider according to the definition of Directive 98/34 (codified by Directive $2015 / 1535)$, that is, a service normally provided for remuneration, at a distance, by means of electronic equipment for the processing (including digital compression) and storage of data, and at the individual request of a recipient of a service.

The European Parliament and the European Commission present a very "platform friendly view". ${ }^{2}$ First, they distinguish the connection service provided by platforms from the underlying service provided, for instance transport or accommodation. In fact, regarding mobility platforms, their approach does not view the service provided by the platform as a new "business model of urban transport", but as an intermediation service. In this view, normally there are three contracts: an intermediation contract between the driver and the platform, an intermediation contract between the passenger and the platform, and a transport contract between the passenger and the driver. According to the European Commission, if platforms limit themselves to match service providers and consumers, that connection service is an information society service and should not be subject to authorization or licence, as they benefit from the Internal Market freedom to provide services under the Treaty rules (Articles 56 to 62 TFEU) and Directive 2006/123 (Directive on Internal Market services) and the E-commerce Directive (2000/31). Even if local regulations apply to the underlying service provider, they do not bind the platform..$^{53}$ Moreover, the specific nature of this service could make the local regulatory frameworks in force for services similar to the one offered through the platform, unfit for purpose. In fact, the first alternative is not favourable to the platform because it may impose such demanding conditions that impedes the survival of the platform, as happened in Denmark where Uber closed its operation in April 2017. Even if platforms are also providers of the underlying local

\footnotetext{
${ }^{51}$ European Commission, Communication from the Commission to the European Parliament, the Council, the European Economic and Social Committee and the Committee of the Regions. A European Agenda for the collaborative economy, COM (2016) 356 final, Brussels, 2.6.2016, 3.

${ }^{52}$ The European Parliament speaks of the increased transparency of platforms. European Parliament, The Cost of Non-Europe..., I-72.

${ }^{53}$ European Commission, A European Agenda for the collaborative economy, 33-34.
} 
service, authorisation or licencing should be imposed only where necessary for reasons of public policy. ${ }^{54}$

The European Parliament ${ }^{55}$ admits the convenience of creating "a hybrid category for information society services" that prevents the risk of a superficial regulatory equality that is an unproportioned burden on the "sharing economy".

The Advocate-General Macjel Szupnar and the CJEU in the case Elite Taxi. held a different view in the cases involving UberX/Pop and found that the platform business was the underlying service of transport. ${ }^{56}$ Regardless of the nature of the contract between the platform and the drivers, ${ }^{57}$ no transport contract was found between the passenger using the platform and the driver. Following the Opinion of the Advocate-General in case Elite Taxi, the Court concluded that the transport service provided to the passenger was organised by Uber. Uber defined its standard features and conditions relating to vehicles and drivers, and the price. ${ }^{58}$ The digital platform that allowed the connection between a passenger demanding a ride and the driver was not separable from the ride service and, therefore, could not be viewed as an autonomous intermediation service. It was the innovative tool of a new business model for transport services, ${ }^{59}$ not a business in itself. Digital platforms brought new global players into the business of urban transport services ${ }^{60}$ which until then, were in the hands of local companies, forcing changes and raising several concerns and regulatory issues. The

\footnotetext{
${ }^{54}$ European Commission, A European Agenda for the collaborative economy, 4.

${ }^{55}$ European Parliament, The Cost of Non-Europe..., 28.

56 To understand the reasoning of the Advocate-General and the Court in the cases before the
} ECJ, see Graça Enes, "Uber and EU law. Information Society Service or Transport? A question of competences," The Sharing Economy. Legal Problems of a Permutations and Combinations Society, Eds. Regina Redinha, Maria Raquel Guimarães and Francisco Liberal Fernandes (Newcastle upon Tyne: Cambridge Scholars Publishing, 2019), 410-438; “The collaborative Economy as a Matter of Competences...”. In most of the cases around the world courts shared the same view that Uber was a transport provider.

57 This issue is also important and was the subject of major litigation in the US and Europe. In the United Kingdom the "Aslam and Farrar saga" concerning the statute of drivers as independent contractors or workers is going on for years. Considering them as workers is an important argument in favour of labelling the service provided by Uber as transport. In the United Kingdom Uber was licenced for five years as a "private hire operator" by Transport for London (TFL) in 2012. The licence was not renewed in 2017 on grounds that Uber did not comply with required standards; after appeal, in 2018 it was granted a provisional licence for 15 months (ending in September 2019) under the scrutiny of TFL after the Westminster Court considered Uber has significantly changed its practices and fulfilled several conditions.

${ }^{58}$ Ownership of key assets used to provide the underlying service was irrelevant contrary to what the European Commission proposed in the Agenda for the Collaborative Economy (in fact, in transport business using not owned vehicles is common).

${ }^{59}$ Advocate-General Macjel Szupnar defines the concept of "transport" as "[c]onveying people or goods from point A to point B" as long as that is the main objective of the activity in question (paragraphs 29 and 34 of the Opinion in cases C-340/14 and C-341/14). Also the European Commission "Handbook on the implementation of the Services Directive", states driving schools services, removal services, car rental, car rental services, funeral services or aerial photography services are not excluded from the scope of Article 2/2/d) of Directive 2006/123, http:// ec.europa.eu/internal_market/services/docs/services-dir/guides/handbook_en.pdf. Regarding the concept of "transport" see also Judgment of 15 October 2015, Grupo Itevelesa and Others, C-168/14, EU:C:2015:685, paragraphs 45 and 46, and Opinion 2/15 (Free Trade Agreement with Singapore) of 16 May 2017, EU:C:2017:376, paragraph 61.

${ }^{60}$ In the US, the United States District Court for the Northern District of California on 18 June 2016 stated "Uber is ultimately a transportation company, albeit a technologically sophisticated one." "Order-Denying-Plaintiffs-Motion-for-Preliminary Approval of Settlement", https://www.cand. uscourts.gov/EMC/OConnorvUber'Technologies. 
first one the CJEU had to deal with was the submission of Uber to national and local rules imposing authorisations and licences on taxis and other urban transport services, instead of the rules governing provision of services in the Single Market, especially information society services (respectively, Directive 2006/123 and Directive 2000/31).

The case of Uber-France approached similar issues but from a different angle: did the restrictions imposed at national level regardless of their respect to transport infringe Directive 98/34 (codified by Directive 2015/1535)? This Act imposes on Member States the obligation to notify the Commission of technical regulations that may hinder the freedom of information society services. Disrespect of such an obligation impedes Member States from imposing those standards on companies. Uber claimed France could not impose the law forbidding the use of digital platforms in transport services because it did not notify the Commission of that rule. According to the Court, that restriction imposed by national rules was not relevant in the context of transport services because these were excluded from the scope of Internal Market rules on freedom to provide services and that same directive excludes from its scope, rules that only in an implicit or incidental manner, affect information society services. The matter deserved more careful consideration. By enacting this law, France distinguishes the transport service from the connection established through a digital platform. ${ }^{61}$ This distinction gives autonomy to this last service and if it is independent, it is naturally an information society service. Forbidding this last one is clearly a restriction on the freedom enshrined in the Treaty and in the Directives 2006/123 and 2000/31. These restrictions should be submitted to the test of public policy reasons and proportionality. The Court simply ignores all that and considers the French law as a regulation on transport. The Richard Leipold case posed similar questions but it was removed from the register the same day of the judgment in Uber France was handed down. ${ }^{62}$

Platforms like Blablacar or Mytaxi presented different and much less demanding regulatory challenges.

The first one corresponds more faithfully to "sharing", since it allows a driver that would anyway do a journey and has a spare seat to share its journey and the costs (instead of profit or remuneration) with another person. The positive effects with regards to efficiency and sustainability are evident; from reducing vehicles on the road from a public policy perspective, a more careful look may be in order, because this may run against the incentives to use public collective transport more "environment and traffic friendly". Despite the influence of the platform over the conditions of the journey, Blablacar was found to provide only an information society service by the Juzgado Mercantil n. 2 de Madrid. ${ }^{63}$ There are three contracts: one between Blablacar and the driver, another between Blablacar and the passenger, both information society services, and a third one of private transport between the driver and the passenger.

The other platforms provide the connection between a professional and licenced

\footnotetext{
${ }^{61}$ In case Uber France (paragraph 22) Advocate General Szupnar declares the control exercised by Uber over the drivers is similar to that of a franchisor over its franchisees. In a franchise relationship, more than a control of the relationship with the customers, it is the use of a brand and the value associated with it that implies an extensive conditioning of the business, mostly accompanied by the provision of support services by the franchisor. This conclusion is contradictory to the reasoning in Elite Taxi because the franchisees conclude and provide directly and by themselves the services to consumers, something that does not happen with Uber drivers.

${ }^{62}$ Graça Enes, "The Collaborative Economy as a Matter of Competences...”, 391.

${ }^{63}$ Sentencia n. ${ }^{\circ}$ 30/2017, 2 February 2017, https://www.lenguajejuridico.com/sentencia-del-juzgadomadrid-caso-blablacar/.
} 
driver with a passenger. Unlike the former case, in this one, the passenger defines the starting point and the point of arrival of the trip. The driver, no matter the payment method, sets the cost of the service. There are three contracts: one intermediation contract between the platform and the driver and in this one, the platform provides the driver with another means (the platform app) to reach clients (especially young people and tourists), a B2B contract; one intermediation contract between the platform and the passenger allowing this access to taxis everywhere around the globe with the same app, a B2C contract; and, one transport contract between the passenger and the driver, a B2C contract too. In respect of the first contract, commercial law is the adequate framework; in respect of the other two, consumer law should apply. Some regulatory challenges emerge regarding business practices and consumer protection (information duties, data protection, etc.).

On the other hand, the parallel made with accommodation platforms where the features and conditions of rental are not set in the same way even by the most prominent platforms is illustrative of the diversity of digital platforms business. Accommodation is inherently a service not fit to a similar standardisation, as is urban transport. On the opposite, global digital platforms like Airbnb or Homeway were able to strive in face of the huge global players in this sector (be they luxury or low cost) offering locally embedded and diverse accommodation that those hotel chains cannot offer. The accommodation characteristics and experience depends heavily on the local provider choices. Also, the price, even if the platform tries to influence (for instance through platform fixing of dynamic prices), it is set by the owner of the accommodation. If the fact that the payment is necessarily run by the platform (and not all platforms impose that condition) is devalued, all these features point to an intermediation service run by the platform and the presence of three contracts (intermediation contract between the platform and the "host": B2B or B2C if the host is a non-professional individual; intermediation contract between the platform and the "guest": B2C; accommodation or house rental between the "host" and the "guest": B2C or P2P). Besides the public policy concerns regarding this sector (gentrification of cities, scarcity of housing, increase of rentals, for instance) some regulatory control may be necessary concerning that intermediation service and the risks of imbalance between the counterparts. This may result from practices such as non-transparent fixing of the rating mechanisms or excessive commissions, and unilaterally imposing contract terms and conditions, some perhaps abusive.

The recent preliminary reference ${ }^{64}$ concerning the intermediation services provided by Airbnb in France proves the regulatory issues are more complex. Should the platforms be classified as tourism agents ${ }^{65}$ or real estate agents? These services may be subject to licencing and conditions imposed by national rules. In the Airbnb preliminary request the Juge d'instruction du tribunal de grande instance de Paris puts the following questions: " 1 . Do the services provided in France by the company Airbnb Ireland UC via an electronic platform managed from Ireland benefit from the freedom to provide services contemplated in Article 3 of Directive 2000/31 of the European Parliament and of the Council of 8 June 2000? 2. Are the restrictive rules relating to the exercise of the profession of real estate agent in France, laid down by Law No. 70-9 of 2 January 1970 on intermediaries in real estate transactions ('the Hoguet Law'),

\footnotetext{
${ }^{64}$ Judgment $Y A$ and AIRBNB Ireland UC, case C-390-18.

${ }^{65}$ In 29 November 2016, the Juzgado Contencioso-Administrativo n. ${ }^{\circ} 11$ de Barcelona found Airbnb platform as an information society service provider and not a tourism agent.
} 
enforceable against the company Airbnb Ireland UC?"

In fact, the regulatory challenges are multiple and complex and the disputes around the world prove that. ${ }^{66}$

\section{Regulatory challenges in the European Union}

\section{The European legal framework - a matter of competences}

The scenario is one of horizontal sparsity and fragmentation overlapping the diversity of the "collaborative economy" and of vertical fragmentation between diverse EU rules that apply despite the absence of a unified political approach at the national, regional or even local level, with their legitimate different approaches in regard of touristic accommodation or urban transport. For instance, in most countries, a transport service provided for a price higher than its cost is generally reserved to taxis or professional drivers. On the other hand, ridesharing a journey that the driver would be doing anyway in order to split costs is not subject to any special regulations. The risks of gentrification and other negative consequences of the touristic boom promoted by "low cost" air travel and temporary house rental for tourists led many cities to approve limitations on this type of renting. ${ }^{67}$

The shortcomings are easy to identify; ${ }^{68}$ uncertainty, misfit of regulations in force for incumbent industries, potential normative conflict, and regulatory loopholes. The European Parliament highlights the negative effects on innovation, competition, and consumers. In some Member States, some of the most prominent platforms were not authorised to fragment the Single Market. ${ }^{69}$ It finds "existing legal provisions are quite sparse and call rationally for a common legal framework at EU level, covering some if not most - activities included in the sharing economy" ${ }^{70}$ It calls for a mix of a topdown and bottom-up approach. The setting of common rules should be progressive, focus on a few sectors and be "with a view to a possible rolling back of legislation in the medium term". ${ }^{71}$

The European Commission policy since 2015 evidences a nuanced evolution.

\footnotetext{
66 The expansion strategy of major platforms "prioritizes market share gain and first mover advantages" and the "buzz" it creates is beneficial because the enthusiasm of its participants works as lobbying to overcome local restrictions on the business. Carmelo Cennamo and Juan Santalo, "Platform competition: strategic trade-offs in platform markets," Strateg. Manag. J., vol. 34, issue 11 (2013): 1331-1350; Parente et al., "The Sharing Economy Globalization Phenomenon...", 55.

${ }^{67}$ The European Commission presents an overview of some of the national regulations on transport in the Staff Working Document Accompanying the document Communication from the Commission to the European Parliament, the Council, the European Economic and Social Committee and the Committee of the Regions - A European Agenda for the Collaborative economy - supporting analysis, SWD (2016) 184 final, Brussels, 2.6.2016, p. 27-30, http:/ / r.search. yahoo.com/_ylt=AwrCOSYUF0VcjlcA2FJXNyoA;_ylu=X3oDMTByOHZyb21tBGNvbG8DYmYxB HBvcwMxBHZ0aWQDBHNlYwNzcg--/RV=2/RE=1548060565/RO=10/RU=http $\% 3 a \% 2 f \% 2 f e c$. europa.eu $\% 2$ fDocsRoom $\% 2$ fdocuments $\% 2$ f16881\% $\%$ fattachments $\% 2 f 3 \% 2$ ftranslations $\% 2$ fen $\% 2$ frendit ions $\% 2$ fnative $/ \mathrm{RK}=2 / \mathrm{RS}=455 \mathrm{C} 1$ YALJaI9dSbFjv6x_uCeavg-.

68 Collaborative economy and traditional providers identified insufficiently adapted regulatory framework and uncertainty as the major concerns. European Commission, Synopsis Report on the Public Consultation on the Regulatory Environment for Platforms, Online Intermediaries and the Collaborative Economy, 2016, p. 21, https:/ / ec.europa.eu/digital-single-market/en/news/full-report-results-publicconsultation-regulatory-environment-platforms-online-intermediaries.

${ }^{69}$ European Parliament, The Cost of Non-Europe..., 26.

${ }^{70}$ European Parliament, The Cost of Non-Europe..., 18.

${ }^{71}$ European Parliament, The Cost of Non-Europe..., 29.
} 
In the Digital Single Market Strategy, ${ }^{72}$ it intended to advance with a new regulatory framework for online platforms. Yet, in that same year, in the Communication on Upgrading the Single Market: more opportunities for people and business, ${ }^{73}$ the Commission seems to favour, instead, a soft law approach to provide guidance on how EU law applies to collaborative economy business models, rather than a mandatory new European legal framework. In 2016, the Commission finds a need for a specific approach to different industries and underlines the danger that "legislation developed for conventional industries is wrongfully applied to markets in the sharing economy". ${ }^{74}$ In the Agenda for the Collaborative Economy, the European Commission follows a cautious approach of clarifying the regulatory environment with the aim of "supporting consumers, businesses and public authorities to engage confidently in the collaborative economy". It intends to monitor the economic development and the regulatory environment at national, European and international levels, through periodic surveys of consumers and business, collecting statistical data end evidence, ongoing mapping of regulatory developments, stakeholder dialogue in the framework of the Single Market Forum to assess the development and identify good practices, with results summarised in the Single Market Scoreboard. Upon that the priority is to encourage the exchange of good practices ${ }^{75}$ analyse how regulatory loopholes need addressing. ${ }^{76}$

Among stakeholders, there is no consensus even if fragmentation was found the major barrier to the development of collaborative economy by the respondents of the Consultation led by the European Commission. ${ }^{77}$ Some caution is in order against a rigid regulatory framework because it may curtail the development of innovation; on the other hand, public policy objectives, consumer rights or fair competition demand some kind of regulation. However, "what kind of regulation"? For some, if the services provided are similar to the ones provided by incumbent industries, regulation should be the same. Others find that special regulation or at least some adaptation is needed.

Though no specific regulatory framework is in force for the "sharing/collaborative economy", law is not absent. European ${ }^{78}$ and national law, be it civil, commercial,

\footnotetext{
${ }^{72}$ European Commission, Communication on online Platforms and the Digital Single Market Opportunities and Challenges for Europe, COM(2016) 288/2, Brussels, 25.5.2015, https:/ / ec.europa.eu/digital-singlemarket/en/news/communication-online-platforms-and-digital-single-market-opportunities-andchallenges-europe.

${ }^{73}$ European Commission, Communication from the Commission to the European Parliament, the Council, the European Economic and Social Committee and the Committee of the Regions, Upgrading the Single Market: more opportunities for people and business Brussels, 28.10.2015, COM(2015) 550 final, https://ec.europa.eu/docsroom/documents/14007?locale=en

${ }^{74}$ European Commission, Synopsis Report on the Public Consultation on the Regulatory Environment for Platforms..., 21.

75 The European Commission sent to Member States a questionnaire entitled "Good practices in promoting Collaborative Economy Businesses" (a summary of the responses can be found in European Commission, Staff Working Document Accompanying the document Communication from the Commission to the European Parliament, the Council, the European Economic and Social Committee and the Committee of the Regions

- A European Agenda for the Collaborative economy - supporting analysis..., 47-49).

${ }^{76}$ European Commission, A European Agenda for the collaborative economy..., 15.

77 European Commission, Synopsis Report on the Public Consultation on the Regulatory Environment for Platforms..., 22-23.

${ }^{78}$ A broad analysis of European law and the collaborative economy can be found in Vassilis Hatzopoulos, The Collaborative Economy and EU law (Oxford: Hart Publishing, 2018); Pieter Van Cleynenbreugel, "Le droit de l'Union européenne face à l'économie collaborative," RTDEur, vol. (oct-dec., 2017): 697-722.
} 
administrative, labor or criminal law may apply.

Several rules of European Union law are relevant. ${ }^{79}$

Primary law: i) Charter of Fundamental Rights: Article 15 (freedom to choose an occupation and right to engage in work), Article 16 (freedom to conduct a business), Article 17 (right to property), Article 20 (equality before the law), Article 21 (nondiscrimination), Article 31 (fair and just working conditions), Article 34 (social security and social assistance); ii) TEU: Article 2 (the values of freedom and non-discrimination), Article 3 (the Internal Market), Article 5 (subsidiarity and proportionality); iii) TFEU: Articles 45 to 48 (freedom of movement for workers), Articles 49 to 55 (right of establishment), Articles 56 to 62 (services), Articles 90 to 100 (transport), Article 102 (abuse of a dominant position in competition), Articles 114 and 115 (approximation of laws in view of the establishment and functioning of or affecting the Internal Market), Article 195 (tourism).

Secondary law general rules - B2C and B2B relations: i) B2C: Directive 2005/29/ EC (Unfair Commercial Practices Directive); Directive 2011/83/EU on consumer rights; Directive 93/13/EEC on unfair terms on consumer contracts; Directive 2013/11/EU on alternative dispute resolution for consumer disputes; Regulation EU/524/2013 on online dispute resolution for consumer disputes; ii) B2B: Directive 2006/114 concerning misleading and comparative advertising.

Secondary law rules relating to services: Directive 2006/123 (provision of services in the Internal Market); Directive 2000/31 (E-commerce); Directive 98/34 (codified by Directive 2015/1535 and laying down a procedure for the provision of information in the field of technical regulations and of rules on Information Society services).

EU rules on transport services: Article 58/1 TFEU refers to "freedom to provide services in transport" and submits these services not to the general rules on freedom to provide services (Articles 56 to 62 TFEU and Secondary Acts enacted by the EU like Directive 2006/123 and Directive 2000/31) but to lex specialis transport policy rules enshrined in Articles 90 to 100 TFEU. ${ }^{80}$ Transport policy has not developed broadly. ${ }^{81}$ Naturally, attention focused on transport services with a transnational dimension and not on urban transport. The European Union did not enact any rules on access and conditions for urban transport services. For now, transport services such as the one provided by digital platforms like Uber are not under the scope of any rules enacted by the European Union. Moreover, Directive 2006/123 (Article 2/2/d) excludes services in the field of transport falling within the scope of Title $\mathrm{V}$ [of Part Three] of the [EC] Treaty [now Title VI of Part Three of the FEU Treaty] and Recital 21 of the Preamble explicitly states: "Transport services, including urban transport, taxis and ambulances as well as port services, should be excluded from the scope of this Directive."

Transport is a shared competence of the European Union and Member States as enshrined in Article 4/2/g) TFEU. According to Article 2/2 TFEU, "[w] hen the Treaties confer on the Union a competence shared with the Member States in a specific area, the Union and the Member States may legislate and adopt legally binding acts in that area. Member States shall exercise their competence to the extent that the Union

\footnotetext{
${ }^{79}$ Enes, "The Collaborative Economy as a Matter of Competences...", 393-394.

${ }^{80}$ These are not exceptional rules. Friedl Weiss and Clemens Kaupa, European Union Internal Market Law (Cambridge: Cambridge University Press, 2014), 242. Opinions of the Advocate-General in cases C-340/14 and C-341/14 (paragraph 28) and Advocate-General N. Wahl in case "Grupo Itevelesa and Others" (C-168/14, EU:C:2015:351, paragraph 22).

${ }^{81}$ Matthias Ruete, "60 ans de politique européenne de transports," Revue du droit de l'Union européenne n. 4 (2018): 35-56.
} 
has not exercised its competence". Since the EU has no rule on this, the setting of conditions for the provision of that service is under the scope of Member State rules and digital platforms such as Uber have to comply with each Member State's rules if they want to provide their services in their respective territory. ${ }^{82}$

After a period of tumultuous conflict with incumbent industries like taxis, some Member States enacted special legislation for the provision of transport through digital platforms. ${ }^{83}$

Being under the scope of national rules does not mean that transport service providers are not under the scope of other Treaty rules like freedom of establishment ${ }^{84}$ and principles like non-discrimination or proportionality. In fact, Member States were since their binding to the Treaty under a "standstill" obligation not to change their national rules in a way to make them "less favourable in their direct or indirect effect on carriers of other Member States as compared with carriers who are nationals of that State." (Article 92 TFEU). In general, Member States "are bound by the obligation of sincere cooperation enshrined in Article 4/3 TEU" meaning they must not hinder European Union law in force and the general principles, including the Charter on Fundamental Rights. They "must exercise their competences consistently with EU law (...), particularly given that the large extent of their powers in transport is not the recognition of an essential State function recognized in Article 4/2 TEU or a power not conferred to the Union." ${ }^{85}$

As for accommodation platforms such as Airbnb, the recent preliminary reference raises some important issues as well. Yet, there are some major differences. First, if the service they provide is an intermediation service distinct from the underlying accommodation service or house rental digital platform, companies are not the providers of accommodation or house rental services. This sector is also highly regulated in all Member States. ${ }^{86}$

The intermediation service provided by digital platforms is under the scope of the rules on freedom to provide services (Article 56 to 62 TFEU, Directive 2006/123) and an information society service under the scope of Directive 2000/31. Any national rules affecting this freedom are subject to Directive 98/34 (codified by Directive 2015/1535) requirements. These Acts intend to promote and simplify

\footnotetext{
${ }^{82}$ Case Elite Taxi, paragraph 47.

${ }^{83}$ In Portugal, Lei ${ }^{\circ} 45 / 2018$ "Lei do transporte em veículo descaracterizado a partir de plataforma eletrónica - TVDE" was enacted in 10 August and is in force since 1 November 2018. This Act seems "tailor-made" to platforms such as Uber. Platforms of the kind of Blablacar or MyTaxi (Article $1 / 3 / 4)$ are explicitly outside its scope. Portuguese law is not very consistent with CJEU case-law. It distinguishes three types of operators: the platform operator, the TVDE operator (necessarily a commercial company), and the driver (necessarily working for a transport operator). The transport service provider is the TVDE operator and not the platform operator. This provides only "the intermediation service between users and TVDE operators adhering to the platform" (Article 16) but is jointly responsible by the transport service provided to passengers [Article 20(1)].

${ }^{84}$ In judgment Yellow Cab Judgment the Court stated that the provisions on freedom of establishment "are applicable directly to transport" (C-338/09, EU:C:2010:814, paragraph 33).

${ }^{85}$ Enes, "The Collaborative Economy as a Matter of Competences...", 393; Perrine Simon, "Uber saisi par le droit du marché intérieur," Revue des Affaires européens, n. 3 (2017): 521-532.

${ }^{86}$ In Portugal besides the "Regime Jurídico dos Empreendimentos Turísticos (RJET)" approved by DecretoLei n. ${ }^{\circ}$ 80/2017, there are several specific regulations for the different types of touristic facilities, http:// business.turismodeportugal.pt/pt/Planear_Iniciar/Como_comecar/Empreendimento_Turisticos/ Paginas/legislacao-empreendimentos-turisticos.aspx; house accommodation provided by "Alojamento local" services is ruled by Decreto-Lei n. ${ }^{\circ}$ 128/2014, modified by Decreto-Lei n. ${ }^{\circ}$ 63/2015 and DecretoLei n. 62/2018. The "Código Civil" rules house rental and several other special rules are apply.
} 
access (Article 5/1 of Directive 2006/123). Reasons of public policy or public interest allow Member States to impose certain requirements such as certificates or attestations always respecting non-discrimination and the proportionality test, under the conditions set by those EU Acts (Article 5/2 of Directive 2006/123). Submission to prior authorisations on establishment is under the strict conditions laid by Articles 9 and 10 of Directive 2006/123. Several requirements are strictly prohibited (Article 14 of Directive 2006/123) and others are subject to evaluation (Article 15 of Directive 2006/123). Besides, the freedom to provide services by providers established in other Member States cannot be hindered by national requirements that do not comply with non-discrimination and proportionality. Some requirements are excluded (Article 16/1 and Article 16/2 of Directive 2006/123), namely imposing the need for a local establishment or infrastructure or even entry in a register with a professional body or association. Any requirements must be justified on grounds of public policy, public security, public health or the protection of the environment (Article 16/3 of Directive $2006 / 123)$. Some case-by-case measures related to the safety of services are admitted under the conditions set by Article 17 of the Directive 2006/123. Directive 2000/31 on information society services too has a liberalising intent and enshrines conditions on requirements imposed by Member States. First, it excludes any prior authorisations on information society services providers (Article 4/1) but without prejudice "to authorisation schemes which are not specifically and exclusively targeted at information society services" [Article 4(2)].

Even if that intermediation service were to classify as a touristic intermediation service and an information society service only in an implicit or incidental manner, they would be submitted to those provisions of the Single Market. Directive 2006/123 includes services like the ones provided by travel agencies or touristic and entertainment services (Preamble, Recital 33)..$^{87}$ Because they are provided by means of a digital platform, they are under the scope of Directive 2000/31. ${ }^{88}$ Reasons of public policy or public interest allow Member States to impose some requirements on the provision of services such as these, for instance registration or liability insurance. In Portugal, the professional service provision of an accommodation reservation is ruled by DecretoLei n. ${ }^{\circ}$ 17/2018 as a tourism and travel agent activity in Article 3(1)(c). Yet, if it is a mere intermediation service for the sale or reservation of single travel services requested by the customer, it does not fall within the services reserved exclusively for travel agents and tourism, according to Article 4(2)(e). This is exactly what happens with on-demand reservation services such as the ones Airbnb provide.

The preliminary reference regarding Airbnb services in France views that activity from a different perspective, as the provision of real estate intermediation services for the temporary rental of a house. These, however, are included in the scope of Directive 2006/123 (Preamble Recital 33) and Directive 2000/31. Again, Member States may impose requirements on providers of those services for reasons of public policy or public interest on the grounds mentioned above. Could these reasons be the

\footnotetext{
${ }^{87}$ Touristic services are also the subject of several EU Acts, like Directive 2015/2302 on package travel and linked travel arrangements, amends Regulation (EC) No. 2006/2004 and Directive 2011/83/EU. Yet, services such as that of digital platforms like Airbnb fall outside the scope of these Acts. In Portugal, it was implemented by Decreto-Lei n. $17 / 2018$, of 8 March, which also regulates broadly access to and exercise of the activity of travel and tourism agencies.

${ }^{88}$ In joined cases C-236/08 to C-238/08, Google France/Louis Vuitton, the Court underlined the key criterion when an online platform is deemed an 'intermediary service provider,' referring to recital 42 to Directive 2000/31.
} 
ground for regulating and imposing requirements like licences or authorisations to that intermediation service? These are precisely the questions put by the French court.

\section{Other challenges: sustainability, liability, labour rights, consumer protection, competition}

The sustainability and social gains claimed by sharing enthusiasts may be questioned. ${ }^{89}$ Users seem to be more motivated by economic gains than those concerns. Lower prices increase the demand and, therefore, consumption will increase with all its externalities. The ecological footprint of massive world tourism created by low cost air travel and accommodation sharing platforms seems to be significant. ${ }^{90}$ With regards to urban mobility, if private cars are underused, they can be used to provide services in mobility sharing platforms, which could improve efficiency and reduce the number of cars in city streets. Yet, things may not be that simple. More pollutant effects result from increased circulation of underused cars and there is a greater wear of the vehicle and need of faster substitution. Moreover, easier access to private transport may prevent a change of habits to collective urban transport, the best environmental alternative and that would have a much more positive effect on the decongestion of city traffic. The distribution of gains seems to favour those that have the most valuable assets "to share" deepening social inequalities.

In this "new economy", the work is organized in projects and using a "liquid workforce" consisting of any user connected to the internet anywhere around the world "able to do the right things in an adaptable, change-ready" 91 and "in many cases (...) for free." 92 Platforms state these persons are not workers, but "entrepreneurs", independent contractors who assume all the risks of the service provided. Uber claimed in Aslam-Farrar to be an "agent" between drivers and passengers. Courts did not accept this view and found platforms liable for damages suffered by recipients of the transport or accommodation service.

If service providers registered in platforms were drivers, couriers or plumbers, they are not workers and thus cannot benefit from labour laws and the platform companies are not bound to pay minimal wage ${ }^{93}$ or to guarantee any working or social protection duties. ${ }^{94}$ Again, the issue went on to courts and decisions were different. ${ }^{95}$

\footnotetext{
${ }^{89}$ Koen Franken, "Editorial, Sustainability perspectives on the sharing economy", Environmental Innovation and Societal Transitions 23 (2017): 1-2, https://ac.els-cdn.com/S2210422417300825/1-s2.0S2210422417300825-main.pdf?_tid=de47e922-b11a-4883-bf59-9b3f424b4a1a\&acdnat =154800520 3_0c941de039c49c15817c24ce1d09506d.

${ }^{90}$ Nikola Mečiarová, "Tourists: what is their ecological footprint?", Ecobnb, 12 March 2018, https:// ecobnb.com/blog/2018/03/tourists-ecological-footprint/; The United Nations Agency for Tourism proposes a policy approach to cope with those issues and promote a sustainable tourism. UNWTO, Tourism and the Sustainable Development Goals - Journey to 2030, Highlights, January 2018, https:/ /www.eunwto.org/doi/pdf/10.18111/9789284419401.

${ }^{91}$ Accenture, Accenture Technology Vision 2016..., 11.

${ }^{92}$ Accenture, Accenture Technology Vision 2016..., 15.

93 A huge part of Uber drivers leaves the company within a year because earnings are below expectations. In 2017, the Federal Trade Commission accused Uber of misleading drivers about how much they could earn, and Uber settled for $\$ 20$ million in early 2017. Noah Smith, "Uber Better Not Be the Future of Work", Bloomberg Opinion, March 8, 2018, https://www.bloomberg.com/opinion/ articles/2018-03-08/uber-drivers-earn-pay-that-s-just-above-the-poverty-line.

${ }^{94}$ One of the major problems has to do with limiting the working hours according with the "working time directive".

${ }^{95}$ The California Labor Commissioner found that a driver was an independent contractor. The Court
} 
In fact, this issue relates to the nature of the service provided by the platform. In the US, courts that considered Uber an intermediation company, found drivers were independent contractors but admitted that if the company was a transport provider the relation with the drivers could be seen in a different light.

In Europe, the most notorious was the "Aslam and Farrar" case that found that drivers were not independent contractors but instead, were under a another category of workers that anyway were entitled to minimal wage and other rights. ${ }^{96}$ The key point is the way Uber controls work details. In the UK, the final report of the "Taylor Review" recommended a new institute of "dependent contractor" adequate to the needs of flexibility of the "new economy". 98

Faced with these challenges, though not recognising them as workers, Uber offers to some of its drivers (independent drivers and drivers working for partner companies but who own the company or are its single driver) automatically and without any cost, a collective insurance contract negotiated at European level. That insurance covers personal damages or death of the driver resulting from car accidents while driving passengers, illness, and parental leave. Nevertheless, it imposes several requirements regarding a minimal threshold of rides accepted. The damage caused to passengers by the same car accidents are not covered by that insurance.

There are also consumer protection challenges. One feature of the "sharing/ collaborative economy" is the increasing amount of services provided transnationally by non-professionals but for a price higher than the cost of the service - P2P services. These services are only under the scope of private contract law but, because of the opportunities offered by the platforms, that provision of services usually becomes regular even if it is not the main activity of the provider. If the activity was to be considered professional, the contracts would fall under the scope of $\mathrm{B} 2 \mathrm{C}$ acts and recipients of services would get better protection. The first issue arising in this regard is the definition of "professional". There is no common one and national laws differ. The Commission ${ }^{99}$ puts forward the following criteria: frequency of service provision;

decided otherwise, https:/ / digitalcommons.law.scu.edu/cgi/viewcontent.coi?referer=\&httpsredir=1 \&article $=1988 \&$ context $=$ historical. In California the first collective action was admitted and even if it was not intended to determine if drivers were independent contractor or employees the common-law "Borello test" applicable to that issue was passed and was found to give some support to the second one. United States District Court, Northern District of California, case O'Connor v. Uber Techs., Inc., No. C-13-3826 EMC, 2013 WL 6354534 (United N.D. Cal), http://www.cand.uscourts.gov/EMC/ OConnorvUber'Technologies.

${ }^{96}$ Judgment of the London Employment Tribunal of October 28, 2016, Aslam, Farrar and Othersv-Uber, case 2202551/2015, https://www.judiciary.gov.uk/judgments/mr-y-aslam-mr-j-farrar-andothers-v-uber/. After an appeal dismissed by the Employment Appeal Tribunal, the case is not over. Last appeal to Court of Appeal was also dismissed on December 19, 2018, case No. A2/2017/3467, https://www.judiciary.uk/wp-content/uploads/2018/12/uber-bv-ors-v-aslam-ors-judgment-19.12.18. pdf, but with a dissenting opinion from Lord Justice Underhill. Another appeal to the UK Supreme Court is to be expected. In June 13, 2018 the Court of Appeal decided in a similar way in regard of "Pimlico Plumbers", https://www.supremecourt.uk/cases/docs/uksc-2017-0053-judgment.pdf.

97 “Good work: the Taylor review of modern working practices", July 2017, https://www.gov.uk/ government/publications/good-work-the-taylor-review-of-modern-working-practices.

98 On this issue see Carmen Grau, "Economia Colaborativa y Trabajadores Independientes: Del Surgimiento de una Nueva Categoria de Trabajadores," Collaborative Economy: Challenges and Oportunities..., 45-64; Esther Guerrero Vizuete, "El Provedor de Servicios en la Economia de las Plataformas: Contradiciones y Ambigüedades desde una Perspectiva Laboral," Collaborative Economy: Challenges and Oportunities..., 65-81.

${ }^{99}$ Agenda for the collaborative economy, 5. 
profit; business turnover. When those criteria are not fulfilled and the relation is truly P2P, is there any need for European regulation or even national one? Because there is a huge increase of transnational low value contracts between non-professionals dispute resolution, according to the rules in force (national and European), this may not be fit. Platforms have their own settlement mechanisms, but these raise some concerns regarding due process (in fact, platforms set and apply the rules themselves). Specific rules may be needed too in relation to data protection in P2P relations.

Another problematic issue in this regard arises from reputation mechanisms. These are a key factor in the sharing/collaborative economy ${ }^{100}$ to build trust in a large and unknown community but they are not very accurate and may raise concerns of privacy protection, exclusion resulting from prejudice, and the because of consequences of bad ratings (Uber disconnects drivers whose ratings are below a certain threshold the company imposes). ${ }^{101}$

Again, in competition law, the new business model brings new challenges, be they the result of partnership with reputed giant corporations ${ }^{102}$ or the risks of "predatory" behaviour of the giant platforms after locking users and other collaborators inside their system. ${ }^{103}$ The specificities of a two-sided business model make it difficult to apply the tests in force in fair competition control.

Incumbent industries like taxis complain of the lack of a level-playing field because this new business model does not abide to regulations and all the restrictions imposed on those, namely licences. After the approval of special regulations, complaints continued because the requirements imposed on platforms are less demanding. ${ }^{104}$

\section{A multilevel constitutionalist approach built upon subsidiarity}

This new economy, "collaborative economy", based on digital platforms, poses several regulatory challenges. Of course, it is not above the law nor outside the law. Besides national law, several European acts apply. However, there is no special regulatory framework in force to cover this entire economic sector.

One difficulty is the immense diversity involved because besides creating new services, most of this new economy is a new way to do business that changed traditional product or service industries, namely transport or accommodation.

The first question is if there is a need for new regulations. If the business is not in itself new, the move from a small-scale activity to a massive one poses new regulatory demands. ${ }^{105}$ In addition, traditional incumbent industries may need regulatory reform.

A major concern is not to hinder but instead, promote innovation. A new

\footnotetext{
100 Steven Tadelis, "Reputation and Feedback Systems in Online Platform Markets," Annual Review of Economics, vol. 8 (2016): 321-340, https://doi.org/10.1146/annurev-economics-080315-015325. Portuguese law does not allow the rating of passengers.

${ }^{101}$ There is a social exclusion general concern in relation of people that is ill adjusted to new technologies. The European Commission does not pay attention to this issue. The European Parliament presents some mitigating solutions (European Parliament, The Cost of Non-Europe..., 29-30).

${ }^{102}$ Parente et al., "The Sharing Economy Globalization Phenomenon...”, 58.

${ }^{103}$ Franken and Shor, "Putting the Sharing Economy into Perspective...", 3.

${ }^{104}$ In Portugal taxis complain the TVDE does limit access and licencing depends only depends only on a registration with the IMT (Instituto da Mobilidade e dos Transportes).

${ }^{105}$ Kellen Zale, "When Everything is Small: The Regulatory Challenge of Scale in the Sharing Economy," 53 San Diego L. Rev. (2016): 949-1016, https:/ / papers.ssrn.com/sol3/papers.cfm?abstract_ $\mathrm{id}=2866044 \#$.
} 
regulatory approach may be necessary if the rules in force are not fit to that end. ${ }^{106}$ The companies claim for a liberal deregulatory approach. Incumbent industries like taxis or hotels claim for stricter regulations on platforms to guarantee a level-playing field. Derek $\mathrm{McKee}^{107}$ argues that platforms impose uneven restrictions and regulations on their partners and are not necessarily freedom enhancing and these may need a regulatory approach from policy makers.

New regulations may also be necessary to respond to the negative externalities produced. If positive effects have worldwide reach (for foreign tourists, for instance), negative externalities are mostly local (effects on local incumbent industries, neighbourhood relations, household policies, urban mobility, etc.). In the European Union, effects at the European level must be accounted for, namely the potential hindering of the Single Market of an outdated and fragmented regulation.

Besides the policy choice in regard of regulatory alternatives, what is the appropriate level to enact regulation? In the European Union, this question takes us to the problem of competences: should regulation be at the European level or should it be left to Member States, including the regional and local level?

The "sharing collaborative economy" is very complex, the regulatory needs and effects of which are multiple and differentiated, and the answer lies in a multilevel constitutionalist approach. Multilevel constitutionalism ${ }^{108}$ is now a solid theoretical approach to explain the nature of European Union and Member States political and legal relation. It is also appropriate to assess regulatory policies. Multilevel constitutionalism detaches State and Constitution and admits a constitutional system beyond the State and interacting with its constitutional order. The European Union inspires this approach and is best suited to trial its validity.

The multilevel constitution of the EU has one major anchor principle: the principle of conferral limits the competences of the European Union (Article 5 TEU) and implies that all competences not conferred to the Union by the Treaties belong to Member States. More important, conferral of competences does not mean that Member States are excluded because some of the competences conferred are exclusive competences of the Union (Article 3 TFEU) but most of them are shared competences. In this last category, not only the Union is entitled to regulate but Member States remain competent to do so as long as the European Union has not ruled [Article 2(2) TFEU]. The enactment of rules by the European Union has a pre-emptive effect and Member States no longer are entitled to rule on the same subjects to the extent the Union has ruled. The multilevel constitution of the European Union is not a layered compound but an interwoven fabric. ${ }^{109}$

This was at the heart of the CJEU Uber cases. Transport policy is one of the shared competences (Article 4/2 TFEU). Uber's services were classified as a transport service. Transport services are not under the general rules of the Treaty (Articles 56 to

\footnotetext{
${ }^{106}$ Parente et al., "The Sharing Economy Globalization Phenomenon...", 55.

${ }^{107}$ Derek McKee, “The platform economy: natural, neutral, consensual and efficient?”, Transnational Legal Theory, vol. 8, issue 4 (2017): 455-495.

${ }^{108}$ This perspective gained wide acceptance since first proposed by Ingolf Pernice's "Bestandssicherung der Verfassungen: Verfassungsrechtliche Mechanismen zur Wahrung der Verfassungsordnung," in The European constitutional area, eds. R. Bieber and P. Widmer (Zürich: Schulthess, 1995), 225. The Author has extensively written and developed this perspective. Recently the multilevel constitutional approach was proposed for the digital economy. Pernice, "Risk Management in the Digital Constellation...".

${ }^{109}$ This intertwining of competences makes the metaphor of the "marble cake" also illustrative of the European Union's multilevel constitutionalism.
} 
$62 \mathrm{TFEU}$ ) on the provision of services but under the leges specialis of transport policy and Directive 2006/123 and Directive 2000/31 enacted by the European Union. Since the Union has not ruled on the conditions to provide that kind of transport, these are under the scope of Member States powers. Member States can legitimately exercise their competence and set the legal framework for that activity according to Article 2/2 TFEU (namely, imposing requirements, authorisations or licencing). Nevertheless, they are subject to general principles like non-discrimination and rules like Article 92 TFEU. Uber may claim access to provide transport services, but it has to comply with the requirements set by national and local rules.

The next question is: should the EU enact rules on urban transport? Transport services are "traditionally regulated more densely"110 and for that reason, they were subject to a separate TFEU title. Urban transport especially may be considered of public interest and for that reason, Article 93 TFEU states: "[a]ids shall be compatible with the Treaties if they meet the needs of coordination of transport or if they represent reimbursement for the discharge of certain obligations inherent in the concept of a public service."

A multilevel constitutionalist approach is helpful. A second anchor principle of the European constitutional system is the subsidiarity principle enshrined in Article 5(3) TEU. Subsidiarity is a proximity principle (Article 1 TEU) that assumes decisions should be taken at the possible closest level to citizens. Because of that, in shared competences, the exercise of powers by the Union must pass the test set out in Article 5/3 TEU and in the Protocol on the principle of subsidiarity and proportionality.

According to Ingolf Pernice, ${ }^{111}$ in line with the multilevel constitutional approach, the digital revolution poses new challenges and risks that ask for new "creative and universal strategies" of management. In our view, the "sharing economy" is a digital business model but it does not demand necessarily global regulations or even European ones. The approach needs to be sector specific and recognise different appropriate levels of regulation from European to national and local level.

Ignoring borders, the digital business model turns every local business into a global business. Article 91 TFEU enshrines a general clause in paragraph 1/d to confer the Union with broad powers to take "any other appropriate provisions". It also asks the legislator to be aware of "the distinctive features of transport" (paragraph 1); states that "account shall be taken of cases where their application might seriously affect the standard of living and level of employment in certain regions, and the operation of transport facilities" (paragraph 2). That is why much of the regulation is left to local authorities.

This is one of the best examples of the importance and reach of the principle of subsidiarity as enshrined in Article 5(3) TEU on the allocation of competences. The European Union should take it seriously. The scale and the effects are essentially regional and local and therefore, it is difficult to pass the subsidiarity test. Transport platforms may have been: "an organic response to regulatory market failures" (Bond 2015 , 95) and local authorities should reform the entire sector of local transport, simplifying and innovating. ${ }^{112}$ In the design of transport policy, local concerns related to mobility, traffic management, urban planning, road safety, and public security are decisive. The appropriate level of regulation is at Member State level and regional and

\footnotetext{
${ }^{110}$ Advocate General Macjel Szupnar Opinion in cases C-340/14 and C-341/14, paragraph 27.

${ }^{111}$ Pernice, "Risk. Management in the Digital Constellation...", Part II, 91.

${ }^{112}$ European Parliament, The Cost of Non-Europe..., 18, 164.
} 
local authorities should take part into formulating the definition of this regulatory policy. Urban mobility needs to be tackled through regulation sensitive to local sensitivities and national and local policy preferences are legitimate, taking into due account the transport network available and the type of city and inhabitants. It is not appropriate to have a uniform legal framework in the EU. Admitting the adequacy of a special legal framework, no restrictions on transport services provided by platforms can jeopardise a public policy to enhance collective transports.

In the United States, it was not up to federal law to regulate transport platforms but instead to States and cities, ${ }^{113}$ and these are setting the new rules for this new business model of transport (TNC) ${ }^{114}$ Europe should follow the same approach and Article 91/2 TFEU signals the concern with effects at local level. Portugal was a pioneer in enacting a special regulatory framework for transport provided by means of a digital platform "and it should be only a matter of time until currently blocked locations are open - probably under stricter rules - for sharing economy firms to operate due to strong popular pressure."'15

Accommodation business even if intermediated by digital platforms is under local and national rules and that is not controversial. Again, the interests at stake and the positive and negative effects are essentially local. Moreover, the European Union has no competences conferred to rule housing policy and the competences regarding tourism are limited "to support, coordinate or supplement the actions of the Member States" (Article 6/d) TFEU, "encouraging the creation of a favourable environment for the development of undertakings in this sector", "promoting cooperation between the Member States, particularly by the exchange of good practice" [Article 195(1) TFEU], and "excluding any harmonisation of the laws and regulations of the Member States" [Article 195(2) TFEU].

The intermediation business provided by digital platforms are under the scope of the rules on the freedom to provide services (Articles 56 to 62 TFEU) and Directives 2006/123 and 2000/31. Member States may impose restrictions like special requirements or authorisations for public policy reasons and make them subject to proportionality and non-discrimination. These national measures certainly hinder the Single Market and must respect Directive 98/34 (codified by Directive 2015/1535). This is the matter under review in the Airbnb preliminary reference.

Should the European Union approve common rules in regard of those public policy requirements to overcome the restrictive effects on national rules? Again, the subsidiarity test must be applied following a multilevel constitutionalist approach.

The challenges mentioned show evidence of transnational dimension and its effects and may demand a European action to decide on a sector specific and a cautious and proportionate approach.

\footnotetext{
113 On the question of the allocation of the exercise competences in the United States in light of the "precautionary principle", see Sarah E. Light, "Precautionary Federalism and the Sharing Economy," 66 Emory Law Journal, vol. 66 (2017): 333-394, http://law.emory.edu/elj/_documents/volumes/66/2/light. pdf; Patrick Gavin, "Regional Regulation of Transportation Network Companies," Harvard Law \& Policy Review, vol. 11 (2017): 337-357, http:// harvardlpr.com/wp-content/uploads/2017/02/HLP105.pdf.

${ }^{114}$ In the US California was the first State to create that new category. 34 States and over 60 cities introduced special regulations for "TNCs-Transportation Network Companies". For an analysis of the Pennsylvania regulation, see Cathorene McKay, "Uber: The Superlative Example in the Class of Transportation Network Companies-Why Pennsylvania’s New Bill Regulating TNCS Is the Key to Their Continued Success in the Sharing Economy," Duq. Bus. L.J. vol. 19 (2017), 51, 74.

${ }^{115}$ Parente et al., "The Sharing Economy Globalization Phenomenon...", 55.
} 


\section{Conclusion}

Digital technologies have a revolutionary potential in the economy and society. It will bring along new business and new ways to do business. The digital platforms that connect people around the world are a good example of this "new economy" and they are the steering engine of the "sharing/collaborative economy". The challenges and risks are also huge, including in law. Old concepts, like transport or worker, and national and European regulatory frameworks are put to the test. The need for new regulations was voiced, namely at European level. The European Parliament and the European Commission issued policy documents. Legal disputes soon appeared, including the application of European Union law versus the Member States' law. This happened in relation to the services provided by Uber and Airbnb. The CJEU was called to adjudicate. In the Uber cases, the Court revisited some ancillary constitutional principles of European Union law regarding competences of the Union and the Member States. The reasoning of the Court resonates a multilevel constitutionalist approach that is enshrined in the Treaties and anchored on conferral and subsidiarity. We believe that to be a very much adequate regulatory perspective for this digital new economy so diverse and complex at one time global and local. 